Global Conferences Series:

Sciences and Technology (GCSST), Volume 3, 2020

The $1^{\text {st }}$ International Conference on Education, Sciences and Technology

DOI: https://doi.org/10.32698/tech3238

\title{
The Difference Effect of Physical Activity Before And After School Toward Physical Fitness And The Ability of Social Interaction in Gajah Mada Medan Primary School Student
}

\author{
Rahma Dewi ${ }^{1}$, Bessy Sitorus Pane $^{2}$, ChairulAzmi $^{3}$ \\ ${ }^{1}$ Departement of Sport Coaching Education, Faculty of Sport Science UniversitasNegeri \\ Medan, Jl. Willem IskandarPsr. V Medan Estate, 20221, Sumatera Utara, Indonesia. \\ ${ }^{2}$ Departement of Sport Coaching Education, Faculty of Sport Science UniversitasNegeri \\ Medan, J1. Willem IskandarPsr. V Medan Estate, 20221, Sumatera Utara, Indonesia. \\ ${ }^{3}$ Departement of Physical Education, Health and Recreation, Faculty of Sport Science \\ Universitas Negeri Medan, Jl. Willem Iskandar Psr. V Medan Estate, 20221, Sumatera Utara, \\ Indonesia
}

\begin{abstract}
The study aims to see the differences of the effect of physical activity before school and after school on physical health and social ability in Gajahmada elementary school students in Medan. The analysis technique used the $\mathrm{T}$ Test with a significance level of $\propto=0$, o5. Obtained: (1) Physical activity before school affect the physical health of students, (2) Physical activity before school affect students 'social ability, (3) Physical activity after school had an effect on students' physical health, (4) Physical activity after school affects students 'social ability (5) Physical activity before school was better than physical activity after school towards physical health of students, (6) Physical activity before school had the same effect as physical activity after school on students' social skills
\end{abstract}

Keywords:Activity, Physical fitness and Social ability

\section{Introduction}

Physical activity or exercise developed in childhood is the basic foundation for the habits that would be possessed for the rest of life. Physical activity enhanced the quality of healthy life for students. There were many studies that show that physical activity was an important factor in getting good health. Physical activity, regulation of food and good sleep habit, help prevent cancer, obesity, diabetes, heart problems, osteoporosis and other common diseases.Regular physical activity had many benefits for children's cognitive and social development. Physical activity that was conducted by participating in complex ways can develop social ability. This could be developed when playing with the peers (Derek et al., 2018). [1].

Problems occurred in the process of learning physical education. In general the implementation of physical education in elementary schools was carried out for only 4 lesson hours with a location of 1 lesson hours for 35 minutes. According to Vega Mareta Sceisarriya in a national seminar on professionalism of professional PJOK. [2] stated that currently the quality of physical education was poor and sad, physical education also was not carried out towards the end of the exam in elementary school.Furthermore, the research findings of Heryudarini H. et al., (2013) [3] stated that the

Copyright (C) 2019, the Authors. Published by Redwhite Press.

Page | 71

This is an open access article under the CC BY-NC license

(http://creativecommons.org/licenses/by-nc/4.0). 
proportion of Indonesian children who do not active was 57.3 dab, the proportion of screen time like TV / computer / PS (two hours or more) per day was 55.2 percent. The proportion of boys (62.8\%) is more inactive than children.Another problem was that social attitudes were increasingly depleting, this was due to easy communication through online media, chat, and conferences that are conducted without need face to face and can be reach only from home or from the office. Just need one media communication can be done at close or long distances, so there was no need to move to socialize and communicate directly.

This lack of understanding of physical benefits had an impact on the implementation of physical education in elementary schools. In fact, do a lot of physical activities and exercises will bring many benefits for children. In order to be useful, it required student need to be involved at least 60 minutes of medium to strong physical activity every day. And still found $30 \%$ of elementary school students did not meet this requirement and $79 \%$ of elementary schools did not carry out the physical education classes every day (Sharma \& Nahar, 2018). [4] This condition also occurred in schools in Medan. The implementation of physical education learning was only carried out 4 lesson hours / week. Learning tended to be dominated by increasing cognitive domains rather than improving student physical health and developing socialization skills.Mostly elementary students showed starting to play in groups. Start looked for friends and showed sympathy for other children.

With those backgrounds, the authors were interested in solving these problems by conducting research "the influence of physical activity before school and physical activity after school towards physical health and social ability in Gajahmada students in Medan" by providing physical activities before school and after school. Giving treatment before school activities refers to the results of research conducted by Yongnam et al (2018) with the finding that physical activity carried out in the morning on elementary students in Korea had an impact on improving physical fitness and social skills. [5] While given the activities after school refers to the research of Ping Xiang (2017) with the findings that on physical activity that carried out after school could improve motivational self-regulation in elementary school students in America. [6] And Weaver et al. (2015) stated that physical activity had many benefits for students if the student do regularly. [7]

Physical activity that carried out regularly would be beneficial to students' physical health for reduction of the risk of degenerative diseases and the risk of obesity (Heryudarini H., et al, 2013). [8] Whereas, inactive physic is related to various health risks, including heart disease, cancer, diabetes, hypertension, anxiety and depression (Kohl and Cook, 2013). [9] Furthermore Erick Burhaein in the Indonesian Journal of Primary Education (2017) stated that physical activity who adapted to growth and development would affect physical growth and optimal emotional development. [10]

Physical education in elementary schools should contain physical activities by playing so the students could develop the movement skills that support their physical growth, knowledge, and social skills. Physical activity was important for children's social life, because friendship developed along with playing physical activity during the first school years (Ingegerd, 2014). [11] Schools could facilitated students to increase the physical activity while in school by encouraging students to move actively, giving students space, facilities, equipment, making structured, attractive physical activities and providing regular time. Physical activity programs before and after school provided opportunities to increase physical activity that provides opportunities for structured and unstructured physical activities and teach children to master the skills needed for lifelong activities (Trost, et al, 2001).[12]

\section{Method}

This study used an experimental research method with two groups of pre-test and post-test designs.The sampling technique used cluster random sampling technique for upper class students at GajahMada Elementary School Medan.Drawing has been conducted to determine the class that used as a class who treated with physical activity before school and physical activity after school.After being randomly randomized, the class will become the experimental group.Before the experiment, the pre-test of physical health and social skills was conducted. After the experiment treated post-test of physical health and social skills also conducted. The physical fitness test used the Indonesian Physical Health test for children aged 10 to 12 years. There were 5 (five) types of tests; (1) Run 40 meters (2) 
Hanging elbows bent, (3) lie down and sit 30 seconds. (4) jump upright and, (5) Run 600 meters. The instrument of social ability used a questionnaire on social skills with indicators: (1) Communication between friends, (2) cooperation between friends, (3) conflict in problems solving, (4) Matching student results. Before the data was analyzed, normality and homogeneity tests were conducted using SPSS version 21. Hypothesis testing uses paired $t$ test and unpaired $t$ test

\section{The results of the research and the discussion}

The results for each group were presented in this following table

Table: 1 . Description and result

\begin{tabular}{llllll}
\hline & $\mathrm{N}$ & Mean & Std. Deviation & Minimum & Maximum \\
\cline { 2 - 6 } Kbpreabs & 95 & 13,60 & 1,300 & 12 & 16 \\
Kbpostabs & 95 & 20,77 & 1,284 & 19 & 23 \\
Kasospreabs & 95 & 75,75 & 4,813 & 67 & 87 \\
Kasospostabs & 95 & 104,88 & 4,829 & 96 & 116 \\
Kbpreass & 95 & 13,55 & 1,295 & 12 & 16 \\
Kbpostass & 95 & 16,53 & 1,515 & 14 & 20 \\
Kasospreass & 95 & 74,79 & 4,764 & 67 & 87 \\
Kasospostass & 95 & 88,15 & 5,186 & 77 & 102 \\
\hline
\end{tabular}

Explanation:

Kbpreabs $=$ Physical health pre-test results for physical activity groups before school Kbpostabs $=$ Physical health post-test results for physical activity groups before school Kasospreabs $=$ Results of the pretest of social skills for physical activity groups before school Kasospostabs $=$ Results of pretest social skills for physical activity groups before school Kbpreass $=$ Physical health pretest results for physical activity groups after school $\mathrm{KBpostass}=$ Physical health post test results for physical activity groups after school Kasospreass $=$ Results of the pretest of social skills for groups of physical activity after school Kasospostass $=$ Results of the pretest of social skills for groups of physical activity after school To test the hypothesis the data was analyzed by t through SPSS. Before the data was processed, the requirements test was conducted by (1) Normality Test and Homogeneity test. The results of Normality test using SPSS showed that data was normally distributed. The full results can be seen in the following table:

Table 2: Summary of Data Normality Test Results

\begin{tabular}{|c|c|c|c|c|c|c|c|c|c|}
\hline \multirow[b]{2}{*}{$\mathrm{N}$} & \multicolumn{2}{|c|}{ Kbpreabs } & Kbpostabs & \multirow{2}{*}{$\frac{\text { Kasospreabs }}{95}$} & \multirow{2}{*}{$\begin{array}{c}\text { Kasospostabs } \\
95\end{array}$} & \multirow{2}{*}{$\begin{array}{c}\text { Kbpreass } \\
95\end{array}$} & Kbpostass & Kasospreass & Kasospostass \\
\hline & 95 & & 95 & & & & 95 & 95 & 95 \\
\hline \multirow{3}{*}{ Normal Parameters ${ }^{\mathrm{a}, \mathrm{b}}$} & Mean & 13,60 & 20,77 & 75,75 & 104,88 & 13,55 & 16,53 & 74,79 & 88,15 \\
\hline & SD & 1,300 & 1,284 & 4,813 & 4,829 & 1,295 & 1,515 & 4,764 & 5,186 \\
\hline & Absolute & ,194 & 199 & 136 & ,143 & 190 & , 160 & 137 & ,104 \\
\hline \multirow[t]{2}{*}{ Most Extreme Differences } & Positive & ,194 & 199 & 136 & 131 & 190 & 138 & 137 & 104 \\
\hline & Negative &,- 133 &,- 126 &,- 133 &,- 143 &,- 132 &,- 160 &,- 129 &,- 103 \\
\hline Kolmogorov-Smirnov Z & 1,88 & & 1,939 & 1,329 & 1,394 & 1,853 & 1,556 & 1,339 & 1,012 \\
\hline Asymp. Sig. (2-tailed) & ,00 & & ,001 & ,058 & ,041 & ,002 & ,016 & ,056 & ,257 \\
\hline
\end{tabular}

a. Test distribution is Normal.

b. Calculated from data.

A summary of the results of the calculation of the variance homogeneity of each group can be seen in the following table.Tests null hypothesis of equal population covariance matrices.

From the table above with the value of the Result Box Test "M obtained 0.539 and the sig value obtained 0.967. The Box value "M < from the sig value 0.967 , conclusion all data were homogeneous. Effect of physical activity before school on physical health of students. This could be seen the probability value / $\mathrm{p}$ value test $\mathrm{T}$ Paired: Result $=0,000$, Value $\mathrm{p}$ value $<0.05$. Means: there were differences in influence between before and after giving physical activity before school to physical 
fitness of students. Effect of physical activity before school on students' socialization skills. This could be seen the probability value / $\mathrm{p}$ value $\mathrm{T}$ test Paired: Results $=0,000$, meaning the value of $\mathrm{p}$ value $<0.05$. Means: there was a difference between before and after giving physical activity before school to students' socializing abilities. Effect of after school physical activity on students' physical fitness. This could be seen the probability value / $\mathrm{p}$ value $\mathrm{T}$ test Paired: Results $=0,000$, meaning the value of $\mathrm{p}$ value $<0.05$ Means: there was a difference between before and after giving physical activity after school to physical fitness.Effect of physical activity before school on students' socialization skills. This could be seen the probability value / $\mathrm{p}$ value $\mathrm{T}$ test Paired: Results $=0,000$, meaning the value of $\mathrm{p}$ value $<0.05$ Means: there was a difference between before and after giving physical activity after school to the ability to socialize students.

Table 3: Summary of paired t test for hypothesis 1, hypothesis 2, hypothesis 3 and hypothesis

\begin{tabular}{|c|c|c|c|c|c|c|c|c|c|}
\hline & & \multicolumn{5}{|c|}{ Paired Differences } & \multirow{3}{*}{$\mathrm{t}$} & \multirow{3}{*}{$\mathrm{df}$} & \multirow{3}{*}{$\begin{array}{l}\text { Sig. } \\
(2- \\
\text { tailed })\end{array}$} \\
\hline & & \multirow[t]{2}{*}{ Mean } & \multirow[t]{2}{*}{$\begin{array}{c}\text { Std. } \\
\text { Deviation }\end{array}$} & \multirow[t]{2}{*}{$\begin{array}{l}\text { Std. } \\
\text { Error } \\
\text { Mean }\end{array}$} & \multicolumn{2}{|c|}{$\begin{array}{l}\text { 95\% Confidence } \\
\text { Interval of the } \\
\text { Difference }\end{array}$} & & & \\
\hline & & & & & Lower & Upper & & & \\
\hline Pair 1 & $\begin{array}{l}\text { Kbpreabs - } \\
\text { Kbpostabs }\end{array}$ & $-7,168$ & , 476 & ,049 & $-7,265$ & $-7,071$ & $-146,759$ & 94 & ,000 \\
\hline Pair 2 & $\begin{array}{l}\text { Kasospreabs - } \\
\text { Kasospostabs }\end{array}$ & $-29,137$ & ,538 & ,055 & $-29,246$ & $-29,027$ & $-527,735$ & 94 & ,000 \\
\hline Pair 3 & $\begin{array}{l}\text { Kbpreass - } \\
\text { Kbpostass }\end{array}$ & $-2,979$ & ,875 & ,090 & $-3,157$ & $-2,801$ & $-33,186$ & 94 & ,000 \\
\hline Pair 4 & $\begin{array}{l}\text { Kasospreass - } \\
\text { Kasospostass }\end{array}$ & $-13,358$ & 1,890 & ,194 & $-13,743$ & $-12,973$ & $-68,882$ & 94 & ,000 \\
\hline
\end{tabular}

From the table above it could be concluded that there were:

\section{Non-Paired Hypothesis Test}

Unpaired hypothesis testing was used to test Hypothesis 4:

Physical activity before school was better than physical activity after school for students' physical health.

Table 4. T Test for Hypothesis

\begin{tabular}{|c|c|c|c|c|c|c|c|c|c|c|}
\hline \multirow{5}{*}{ KB } & \multicolumn{6}{|c|}{ Levene's Test for Equality of Variances } & \multicolumn{4}{|c|}{ t-test for Equality of Means } \\
\hline & & \multirow[t]{2}{*}{$\mathrm{F}$} & \multirow[t]{2}{*}{ Sig. } & \multirow[t]{2}{*}{$\mathrm{t}$} & \multirow[t]{2}{*}{ df } & \multirow[t]{2}{*}{$\begin{array}{l}\text { Sig. (2- } \\
\text { tailed) }\end{array}$} & \multirow[t]{2}{*}{$\begin{array}{c}\text { Mean } \\
\text { Differ } \\
\text { ence }\end{array}$} & \multirow[t]{2}{*}{$\begin{array}{l}\text { Std. Error } \\
\text { Difference }\end{array}$} & \multicolumn{2}{|c|}{$\begin{array}{c}95 \% \\
\text { Confidence } \\
\text { Interval of the } \\
\text { Difference }\end{array}$} \\
\hline & & & & & & & & & Lower & Upper \\
\hline & $\begin{array}{l}\text { Equal variances } \\
\text { assumed }\end{array}$ & 4,454 &, 036 & 30,446 & 188 &, 000 & 6,116 & ,201 & 5,720 & 6,512 \\
\hline & $\begin{array}{l}\text { Equal variances } \\
\text { not assumed }\end{array}$ & & & 30,446 & 182,103 &, 000 & 6,116 & ,201 & 5,719 & 6,512 \\
\hline
\end{tabular}

From the table above it could be concluded that:

Physical activity after school was better than physical activity after school for physical fitness of students. This could be seen the probability value / $\mathrm{p}$ value T test Paired: Results $=0.036$, meaning the value of $p$ value $<0.05$. Means: physical activity before school had a better effect than after school on physical fitness.Unpaired hypothesis testing was used to test Hypothesis 6: 


\section{Discussion}

The results showed that there was an effect of giving physical activity before school to students' physical health. Physical activity that was conducted before school was a physical activity designed to improve students' physical health. Physical activity affects all components of physical health. Physical activities that were conducted continuously such as sports with the forms of the game would be more enjoyed and beneficial for those who do sports.There was an effect of physical activity before school on the socialization abilities of students. Physical activities that were conducted before school through forms of play would create interaction and social contact among students. This was reflected in the form of cooperation, talking to each other, supporting each other, competing with each other, so that social skills could be realized in elementary school children.

There was an effect of physical activity after school on physical health of students. Physical activity that was conducted routinely at least 3 times a week would improve students' fitness and health. As long as the physical activity conducted regularly the physical fitness of students would be maintained. The impact was that students become more active and have good physical health.There was an effect of after school physical activity on students' socialization abilities. As a humans being, people need to interact with others. As social being, socializing was already a necessity of life that must be fulfilled. In elementary school students, during the motion activities were given even though school hours have ended social activities were still carried out. Moreover, given the physical activity that has already designed after school, elementary school children could have increased their social skills. Children were happy for collaborative activities, help friends, support and compete with each other.Physical activity before school had a better effect than after school on physical fitness. Based on research data, physical activity before school was better than the results for improving physical health of students. Physical activity that was conducted in the morning before school showed that physical activity was effective in reducing the percentage of body fat and increasing muscle mass and increasing cardiorespiratory endurance. Activities in the morning also revitalize the body's metabolism, so that the calories in the body would burn more. The physical condition of children in the morning before school was still good, had not experienced physical fatigue. Because physical activity will increase energy and energy expenditure (burning calories), then if done after school the results cannot increase physical fitness to the maximum. This was due to the physical condition of children who have experienced physical fatigue and thinking because they have done less learning activities more than 5 hours in class

\section{Conclusion}

Physical activity after school had the same effect as physical activity after school on social skills. Socializing was a need that must be owned by all human being. When physical activity was given before school and after school through the types of motion games, it would increase children's ability to interact, help each other, working together. As long as physical activity was well designed, whenever physical activity was given, social skills would increase.

\section{References}

[1] Derek M.Griffith,ErinM.begner, Emily Cornish, Chelsea M.Mcqueen.Physical Activity Interventions With African American or Latino Men.2018.American Journal of men s Health 12(1): 155798831876364.

[2] VegaMareta Sceisarriya.2017.ProblematikaPelaksanaanPendidikanJasmani di SekolahDasar.Prosiding Seminar NasionalPascasarnaUniversitasNegeriMalang dengantemaProfesionalismeTenagaProfesiPendidikanJasmani, Olahraga, danKesehatan.

[3] HeryudariniHarahap.Sandjaja. , KarlinaNurCahyo. 2013. Polaaktivitasfisikanakusia 6,0-12,9 tahun di Indonesia.JounalGizi Indonesia 36(2):99-108.

[4] Manoj Sharma, Vinayak K. Nahar 2018. Promoting physical activity in upper elementary children using multi-theory model (MTM) of health behavior change. Journal of preventive medicine and Hygiene. Vol 59, No 4. 
[5] Yongnam Park, Jongho Moon. 2018. Effects of Early Morning Physical Activity on Elementary School Students' Physical Fitness and Sociality. International Electronic Journal Of Elementary Education. Volume 10, Issue 4, 441-447.

[6] Ping Xiang, BulentAgbuga,Jiling Liu, Ron E Mc Bride.2017.Relatedness Need Satisfaction, Intrinsic Motivation, and Engagement in Secondary School Physical Education. Volume 36 Issue 3.

[7] Weaver RG, Beets MW, Huberty J, Freedman D, Turner-Mcgrievy G, Ward D.Physical activity opportunities in afterschool programs.Published online 2015 Jan 13. doi: $10.1177 / 1524839914567740$

[8] HeryudariniHarahap.Sandjaja. , KarlinaNurCahyo. 2013. Polaaktivitasfisikanakusia 6,0-12,9 tahun di Indonesia.JounalGizi Indonesia 36(2):99-108.

[9] Kohl dan Cook, 2013.Educating the Student Body: Taking Physical Activity and Physical Education to School. National Academies press (US).ISBN: 0.978-0-309-28313-7

[10] Erick Burhaein. 2017.AktivitasFisikOlahragauntukPertumbuhandanPerkembanganSiswa SD. Indonesian Journal of Primary Education. Vol 1 No 1 51-58.

[11] Ingegerd Renate Ericsson, 2014. Effects of motor skills training and daily physical education. International Journal of Physical Education.

[12] Trost SG, Kerr LM,Ward DS, Pate RR.2001.Physical activity and determinants of physical activity in obese and non-obese children.Jun;25(6):822-9.(PubMed). 